\title{
Allogeneic stem cell transplantation can improve outcome of AML patients without complete cytogenetic response after induction and consolidation treatment
}

\author{
P. DVORAK ${ }^{1,2, *}$, D. LYSAK ${ }^{3}$, S. VOKURKA ${ }^{3}$, M. KARAS ${ }^{3}$, I. SUBRT ${ }^{1}$ \\ ${ }^{1}$ Institute of Medical Genetics, University Hospital Pilsen, Faculty of Medicine in Pilsen, Charles University in Prague, Pilsen, Czech Republic; \\ ${ }^{2}$ Institute of Biology, Faculty of Medicine in Pilsen, Charles University in Prague, Pilsen, Czech Republic; ${ }^{3}$ Department of Haematology and \\ Oncology, University Hospital Pilsen, Pilsen, Czech Republic
}

${ }^{*}$ Correspondence: Pavel.Dvorak@lfp.cuni.cz

Received April 2, 2014 / Accepted May 19, 2014

\begin{abstract}
Our retrospective analysis was performed on 376 consecutive patients diagnosed with AML. A total of 256 (68\%) were treated with standard " $7+3$ " induction and high-dose cytarabine and mitoxantrone containing " $4+3$ " consolidation/ intensification regimens. Our study focused on patients with presumably very poor prognosis - patients, who did not achieve complete cytogenetic remission (CRc). Twenty-five AML patients without CRc were further analysed for clinical and laboratory parameters. Firstly, the subgroups with or without morphologic CR were compared. Similar cytogenetic abnormalities were observed in both with myelodysplasia related changes being the most common. Complex karyotype with deletion of $5 \mathrm{q}$ constituted approximately a third of all karyotypes in both subgroups. There were 1 patient with intermediate risk cytogenetics in the subgroup without morphologic CR and 5 patients in the subgroup with morphologic CR. Interestingly, in $4 / 25$ patients subclones were diminished by the chemotherapy treatment, however cytogenetically less advanced clones proliferated. Secondly, transplanted or nontransplanted patients were analysed. Allogeneic stem cell transplantation (allo-SCT) was found to be the only curative treatment for patients without CRc after $7+3$ and $4+3$ regimens. In our cohort, $40 \%$ of the patients, who underwent allo-SCT, are alive. Importantly, $67 \%$ of the patients, who died after allo-SCT, died of causes unrelated to progression of AML. Nonrelapse mortality is therefore one of the fields where survival could be further improved.
\end{abstract}

Key words: acute myeloid leukaemia, complete cytogenetic remission, cytogenetic abnormalities, stem cell transplantation, nonrelapse mortality

The prognostic importance of some cytogenetic abnormalities identified at diagnosis of acute myeloid leukaemia (AML) has been proved in many extensive studies. Cytogenetic abnormalities were also largely reflected in the latest WHO classification of tumours of haematopoietic and lymphoid tissues [1]. Furthermore, the international working group led by Cheson recommended to use the achievement of complete cytogenetic remission (CRc) after chemotherapy as one of the most important criteria for assessment of treatment outcomes already in 2003 [2]. However, only a few studies focusing on this topic have been published. In fact, a detailed analysis of clinical data together with cytogenetic characteristic of AML patients, who failed to achieve CRc after induction and consolidation/intensification chemotherapy, has not been published so far. This study adds to the limited amount of research in this important field.

\section{Materials and methods}

Our retrospective analysis was performed on a cohort of 376 consecutive patients, who were diagnosed with AML at University Hospital Pilsen between January 2000 and December 2012. A total of 256 (68\%) of these patients were treated with the " $7+3$ " induction and high-dose cytarabine and mitoxantrone containing " $4+3$ " consolidation/intensification regimens (both regimens are described below), $71(19 \%)$ were maintained with a different type of chemotherapy or got only $7+3$ regimen and 49 (13\%) were given 
symptomatic therapy. Clinical and laboratory data from 256 patients treated with both regimens were further analysed. The study was approved by the Ethics Committee at our institution and conducted in accordance with the Declaration of Helsinki.

Chromosome G-banding analysis in combination with FISH analysis was performed in unstimulated 24-h cultures of bone marrow samples according to standard procedures. At least 20 metaphase cells were fully analysed to exclude any clonal abnormalities in accordance with ACC (Association of Clinical Cytogeneticists) and UK NEQAS (National External Quality Assessment Schemes) guidelines for clinical cytogenetics. The clonal abnormalities were described according to ISCN 2013 guidelines [3]. Complex karyotype (CK) was defined, in agreement with the WHO 2008 classification [1], as karyotype with 3 or more unrelated abnormalities. Molecular genetic techniques were performed according to standard protocols. The presence of these molecular genetic abnormalities was detected: MLL-PTD, FLT3-ITD, FLT3 Asp835, GSTM1 and GSTT1 polymorphisms, Cyclin D1 and BAALC overexpression, and NPM1 mutations.

Overall survival (OS) was measured from the date of initial treatment until the date of death and censored on the date of the last follow-up if alive. Progression free survival (PFS) was measured from the date of remission until the date of relapse or death and censored on the date of last follow-up if alive. Descriptive statistics were calculated. Kaplan-Meier curves were used to estimate unadjusted OS and PFS. Log-rank tests were used to compare each time-to-event variable between groups. The Cox proportional hazards regression model was used to evaluate the ability of the relevant variables to predict either OS or PFS. SAS 9.3 software (SAS Institute Inc., Cary, $\mathrm{NC}$, USA) was used for statistical analyses.

Two chemotherapeutic attempts to achieve complete remission (CR) of AML (in line with Cheson et al. [3]) meant application of induction chemotherapy according to $7+3$ regimen followed by consolidation/intensification chemotherapy according to $4+3$ regimen ( $\mathrm{HiDAC}+\mathrm{Mx}$ ). The $7+3$ regimen consisted of: cytarabine $200 \mathrm{mg}$ /day i.v. continuously for 7 days, idarubicin $12 \mathrm{mg} / \mathrm{m}^{2} /$ day i.v. for 3 days. The $4+3$ regimen consisted of: cytarabine $1500-3000 \mathrm{mg} / \mathrm{m}^{2}$ (reduced doses for elderly patients) twice daily i.v. for 4 days, mitoxantrone 10$12 \mathrm{mg} / \mathrm{m}^{2} /$ day i.v. for 3 days.

In patients in complete or partial remission after the two chemotherapeutic attempts, the allogeneic stem cells transplantation (allo-SCT) was performed within the period of 2-8 weeks after the last chemotherapy regimen. Allo-SCT with reduced intensity conditioning regimen FLU/MEL was administered in elderly patients (the age 50 -years and more) and consisted of fludarabine $30 \mathrm{mg} / \mathrm{m}^{2}$ i.v. once daily for 4 days (total dose $120 \mathrm{mg} / \mathrm{m}^{2}$ ) and melphalan $140 \mathrm{mg} / \mathrm{m}^{2}$ i.v. once daily one day prior to transplantation. In young patients, the conventional $\mathrm{Bu} / \mathrm{CY} 2$ conditioning regimen was administered and consisted of busulphan $4 \mathrm{mg} / \mathrm{kg}$ p.o. or $3,2 \mathrm{mg} /$ $\mathrm{kg}$ i.v. in divided doses for 4 days (total dose $16 \mathrm{mg} / \mathrm{kg}$ ) and cyclophosphamide $60 \mathrm{mg} / \mathrm{kg}$ once daily i.v. for 2 days (total dose $120 \mathrm{mg} / \mathrm{kg}$ ).

\section{Results}

Normal karyotype at diagnosis was detected in 120 (47\%) out of 256 AML patients treated with $7+3$ and $4+3$ regimens. Abnormal karyotype was found in remaining 136 (53\%) patients. CRc was not achieved in 25 (18\%) patients following two cycles of chemotherapy. Morphologic CR was not reached in 9 of these 25 patients (no CR/ no CRc; group A). The rest of these patients without $\mathrm{CRc}$ (16 patients) achieved morphologic $\mathrm{CR}$ (CR/ no CRc; group B).

A total of 9 patients (4 males and 5 females) were included in the group A. 6 patients were diagnosed with "AML with myelodysplasia related changes" (AML-MRC), 2 patients with "AML with $\operatorname{inv}(3)(\mathrm{q} 21 \mathrm{q} 26) / \mathrm{t}(3 ; 3)(\mathrm{q} 21 ; \mathrm{q} 26)$ " and 1 patient with "treatment related AML" (t-AML). Clinical data of group A patients are summarized together with group $B$ patients in the Table 1 . Only 2 group A patients were found to be suitable for allo-SCT, the rest had disease resistant to all administered chemotherapy and sustained on symptomatic therapy. One of these 2 patients undergoing allo-SCT is alive 6 months after the diagnosis and the other died of pneumonia after 6 months. All of the 7 nontransplanted patients died due to the disease progression.

In the group A, 7 out of 9 patients (78\%) had a complex karyotype. The assumed primary cytogenetic changes in CK were: abnormality of $5 q$ in 3 patients, abnormality of $3 q$ in 2 patients, abnormality $1 \mathrm{p}$ or $9 \mathrm{q}$ in 1 patient and abnormality of $11 \mathrm{q}$ in 1 patient (Table 2). Abnormalities of $7 \mathrm{q}$ were present in 4 patients and abnormality of $17 \mathrm{p}$ in 2 patients, presumably as secondary changes. Noncomplex karyotypes were present in 2 patients: 46,XY,inv(3)(q21q26)[6]/45,idem,-7[19] and $47, \mathrm{XY},+8[3] / 46, \mathrm{XY}[16]$ respectively. Interestingly, in 1 patient (patient No. 4) the karyotype 45,XX,der(1)t(1;6)(p33;?),der(6) $\mathrm{t}(1 ; 6)(\mathrm{p} 33 ; \mathrm{q} 23) \mathrm{t}(6 ; 9)(\mathrm{p} 11 ; \mathrm{p} 1$ ?3),-9[3]/46,idem,+10[16] was revealed at diagnosis, however the subclone with trisomy 10 (secondary change in this case) was diminished by the chemotherapy treatment and the main clone with no recurrent primary change expanded. Complete karyotypes including FISH results of the group A patients are shown in the Table S1 in the Supplemented Materials. The patient with trisomy 8 as a sole abnormality was positive for NPM1 mutation and overexpression of BAALC in molecular genetic analysis (Table 3).

Sixteen patients ( 8 males and 8 females) were included in the group B. Eleven patients were diagnosed with "AML with myelodysplasia related changes" (AML-MRC), 1 patient with "AML with $\operatorname{inv}(3)(\mathrm{q} 21 \mathrm{q} 26) / \mathrm{t}(3 ; 3)(\mathrm{q} 21 ; \mathrm{q} 26)$ " and 4 patients with "AML not otherwise specified" (AML-NOS) (Table 1). Allo-SCT was performed in 13 patients. Five of these 13 patients are alive $(6,8,64,66$ and 79 months from diagnosis) and 8 patients died. Only 3 of these 8 patients died on disease progression and conversely 5 patients died on reasons not di- 
Table 1. Clinical data of 25 patients without $\mathrm{CRc}$ after $7+3$ and $4+3$ regimens

\begin{tabular}{|c|c|c|c|c|c|c|c|c|c|c|c|c|c|c|}
\hline $\begin{array}{c}\text { P. } \\
\text { No. }\end{array}$ & Sex & Age & $\begin{array}{l}\text { Previous } \\
\text { Chemo- } \\
\text { therapy }\end{array}$ & $\begin{array}{c}\text { Previous } \\
\text { Actino- } \\
\text { therapy }\end{array}$ & $\begin{array}{c}\text { Dg. (WHO } \\
\text { 2008) }\end{array}$ & $\begin{array}{c}\text { Disease } \\
\text { Status after } \\
7+3\end{array}$ & $\begin{array}{c}\text { CR after } \\
7+3 \text { and } \\
4+3\end{array}$ & $\begin{array}{l}\text { Allo- } \\
\text { SCT }\end{array}$ & Donor & GVHD & $\begin{array}{c}\text { PFS } \\
\text { (months) }\end{array}$ & Alive & $\begin{array}{c}\text { OS } \\
\text { (months) }\end{array}$ & Cause of death \\
\hline 1 & $\mathrm{~F}$ & 61 & No & No & AML-MRC & resistant & No & No & No & No & 2.3 & No & 9.2 & resistant disease \\
\hline 2 & M & 50 & No & No & AML-MRC & PR & No & No & No & No & 2.6 & No & 3.0 & progresion \\
\hline 3 & $\mathrm{~F}$ & 44 & No & No & AML-MRC & resistant & No & No & No & No & 1.4 & No & 4.3 & progresion \\
\hline 4 & $\mathrm{~F}$ & 63 & No & No & AML-MRC & resistant & No & No & No & No & 2.0 & No & 5.5 & progresion \\
\hline 5 & $\mathrm{~F}$ & 60 & No & No & AML-MRC & resistant & No & No & No & No & 1.9 & No & 3.2 & progresion \\
\hline 6 & M & 25 & No & No & $\begin{array}{c}\text { AML with } \\
\operatorname{inv}(3)\end{array}$ & resistant & No & Yes & $\mathrm{R}$ & Yes & 6.7 & Yes & 6.7 & \\
\hline 7 & M & 62 & No & No & $\begin{array}{l}\text { AML with } \\
\operatorname{inv}(3)\end{array}$ & resistant & No & No & No & No & 2.0 & No & 2.3 & resistant disease \\
\hline 8 & M & 61 & No & No & AML-MRC & resistant & No & No & No & No & 2.0 & No & 2.0 & pneumonia \\
\hline 9 & $\mathrm{~F}$ & 62 & Yes & Yes & $\mathrm{t}-\mathrm{AML}$ & resistant & No & Yes & $\mathrm{R}$ & No & 4.8 & No & 6.6 & pneumonia \\
\hline 10 & M & 44 & No & No & AML-MRC & resistant & Yes & Yes & $\mathrm{R}$ & No & 2.9 & No & 13.9 & progresion \\
\hline 11 & $\mathrm{~F}$ & 52 & No & No & AML-MRC & $\mathrm{PR}$ & Yes & Yes & $\mathrm{U}$ & Yes & 23.2 & No & 24.4 & pneumonia \\
\hline 12 & M & 62 & No & No & AML-MRC & PR & Yes & No & No & No & 2.8 & No & 3.5 & progresion \\
\hline 13 & M & 56 & No & No & AML-MRC & $\mathrm{PR}$ & Yes & No & No & No & 5.7 & No & 8.8 & progresion \\
\hline 14 & $\mathrm{~F}$ & 63 & No & No & AML-NOS & $\mathrm{CR}$ & Yes & Yes & $\mathrm{U}$ & Yes & 5.4 & No & 5.4 & GVHD \\
\hline 15 & M & 57 & No & No & AML-MRC & PR & Yes & Yes & $\mathrm{U}$ & Yes & 24.4 & No & 24.4 & lung failure \\
\hline 16 & $\mathrm{~F}$ & 50 & No & No & AML-MRC & $\mathrm{PR}$ & Yes & Yes & $\mathrm{R}$ & No & 79.3 & Yes & 79.3 & \\
\hline 17 & M & 53 & No & No & AML-MRC & CR & Yes & Yes & $\mathrm{U}$ & Yes & 13.9 & No & 15.3 & CNS infection \\
\hline 18 & $\mathrm{~F}$ & 47 & No & No & AML-MRC & $\mathrm{PR}$ & Yes & Yes & $\mathrm{U}$ & Yes & 36.4 & No & 57.6 & progresion \\
\hline 19 & $\mathrm{~F}$ & 48 & No & No & AML-MRC & $\mathrm{PR}$ & Yes & Yes & $\mathrm{U}$ & Yes & 6.5 & No & 7.4 & suicide \\
\hline 20 & M & 63 & No & No & AML-MRC & $\mathrm{CR}$ & Yes & Yes & $\mathrm{U}$ & Yes & 5.9 & Yes & 6.7 & \\
\hline 21 & $\mathrm{~F}$ & 56 & No & No & AML-MRC & PR & Yes & Yes & $\mathrm{U}$ & Yes & 8.3 & Yes & 8.3 & \\
\hline 22 & $\mathrm{~F}$ & 63 & No & No & $\begin{array}{c}\text { AML with } \\
\mathrm{t}(3 ; 3)\end{array}$ & resistant & Yes & No & No & No & 3.9 & No & 4.0 & progresion \\
\hline 23 & $\mathrm{~F}$ & 52 & No & No & AML-NOS & $\mathrm{PR}$ & Yes & Yes & $\mathrm{U}$ & Yes & 64.0 & Yes & 64.0 & \\
\hline 24 & $\mathrm{~F}$ & 54 & No & No & AML-NOS & resistant & Yes & Yes & $\mathrm{R}$ & Yes & 66.8 & Yes & 66.8 & \\
\hline 25 & M & 66 & No & No & AML-NOS & $\mathrm{CR}$ & Yes & Yes & $\mathrm{U}$ & Yes & 32.4 & No & 38.9 & progresion \\
\hline
\end{tabular}

$\mathrm{Dg}$.=diagnosis; $\mathrm{CR}=$ complete remission; Allo-SCT=allogeneic stem cell transplantation; $\mathrm{R}=$ related; $\mathrm{U}=$ unrelated; $\mathrm{GVHD}=$ graft versus host disease;

$\mathrm{PFS}=$ progression free survival; $\mathrm{OS}=$ overall survival;

rectly related to disease progression (pneumonia, graft versus host disease, lung failure, CNS infection, and suicide).

In the group B, CK was found in 7 patients (44\%) and 9 patients had noncomplex karyotypes. The assumed primary

Table 2. Primary cytogenetic changes of 9 patients without hematological remission after $7+3$ and $4+3$ regimens

\begin{tabular}{llllllllll}
\hline Abn.|P.No. & $\mathbf{1}$ & $\mathbf{2}$ & $\mathbf{9}$ & $\mathbf{3}$ & $\mathbf{6}$ & $\mathbf{7}$ & $\mathbf{5}$ & $\mathbf{4}$ & $\mathbf{8}$ \\
\hline Complex karyotype & $\mathrm{X}$ & $\mathrm{X}$ & $\mathrm{X}$ & $\mathrm{X}$ & & $\mathrm{X}$ & & $\mathrm{X}$ & $\mathrm{X}$ \\
\hline Abn. 5q/-5 & $\mathrm{X}$ & $\mathrm{X}$ & $\mathrm{X}$ & & & & & & \\
Abn. 3q & & & & $\mathrm{X}$ & $\mathrm{X}$ & $\mathrm{X}$ & & & \\
Trisomy 8 & & & & & & & $\mathrm{X}$ & & \\
Abn. 1p & & & & & & & & & \\
Abn. 9q/-9 & & & & & & & & $\mathrm{X}$ & \\
Abn. 11q & & & & & & & & $\mathrm{X}$ & \\
\hline
\end{tabular}

Abn.=abnormality; cytogenetic changes in CK were: abnormality of $5 q$ in 6 patients and abnormality of $12 \mathrm{p}$ in 1 patient (Table 4 ). Abnormality of $7 \mathrm{q}$ was present in 3 patients and abnormality of $17 \mathrm{p}$ in 2 patients, presumably as secondary changes. Primary cytogenetic changes observed in the noncomplex karyotypes were: $\operatorname{der}(7) \operatorname{del}(7)(\mathrm{p} 12) \operatorname{del}(7)(\mathrm{q} 11.2) ;+8$ (3 patients); $\mathrm{t}(2 ; 3)$ (p13;q26); $\operatorname{del}(7)(\mathrm{q} 22 \mathrm{q} 36) ; \mathrm{t}(3 ; 3)(\mathrm{q} 21 ; \mathrm{q} 26) ; \mathrm{t}(9 ; 11)(\mathrm{p} 22 ; \mathrm{p} 15) ;$ del(20)(q11.2). In 3 patients subclones were reduced by the chemotherapy treatment, however main clones or other subclones proliferated. After the chemotherapy, subclone with monosomy 7 was diminished in the patient No. 11, subclones unseen at the diagnosis were detected in the No. 17 and on the other hand main clone with the sole abnormality - deletion of $5 \mathrm{q}$ - unseen at diagnosis was present in the No. 21. Complete karyotypes including FISH results of the group B patients are shown in the Table S2 in the Supplemented Materials. One of the 5 patients with intermediate risk cytogenetics was positive for NPM1 mutation 
and overexpression of BAALC and 2 patients were positive for overexpression of BAALC in molecular genetic analysis (Table 3).

All of the patients from the groups A and B were included in the statistical analysis. Median follow-up for the whole group (25 patients) was 7.4 months, median PFS was 0.5 years and median OS was 0.8 years. Statistically significant differences in survival parameters were found between two groups - transplanted and nontransplanted patients. PFS and OS were significantly higher than patients who underwent allo-SCT in comparison to nontransplanted group. PFS and OS in transplanted patients were 2.7 and 2 years, in nontransplanted patients 0.2 and 0.3 years respectively (Log-Rank test, $\mathrm{P}=0.0001$, Figure 1 and Figure 2). Patients without transplantation had 22.8 times higher risk of disease progression and 12.5 times higher risk of death (Cox Regression Hazard Model).

\section{Discussion}

In 1997, Grimwade et al. [4] published the results of the 10th UK MRC AML trial. One of the trail's objectives was to determine the role of autologous bone marrow transplantation in AML patients lacking an HLA-matched sibling. Among 101 of 190 patients with AML characterised by abnormal karyotype at diagnosis, persistence of the disease-related clone in eight patients $(8 \%)$, revealed by conventional cytogenetic assessment at bone marrow harvest whilst in morphologic CR, was found to predict a poor prognosis [4].

Fung et al. [5] reviewed the records of 68 patients who consecutively underwent transplantation at the City of Hope Cancer Center with allogeneic SCT for primary refractory AML between July 1978 and August 2000. Allogeneic SCT can cure approximately one third of patients with primary refractory AML. Cytogenetic characteristics before SCT correlate with transplantation outcome and posttransplantation relapse [5].

AML patients treated on Cancer and Leukemia Group $B$ front-line studies were included in the work of Marcucci et
Table 3. Molecular genetic results of 25 patients without CRc after $7+3$ and $4+3$ regimens

\begin{tabular}{cc}
\hline P.No. & Positive molecular genetic results \\
\hline 1 & NPM1 \\
2 & neg. \\
3 & unk. \\
4 & FLT3/ITD, BAALC \\
5 & BAALC \\
6 & BAALC \\
7 & neg. \\
8 & NPM1, BAALC \\
9 & BAALC \\
10 & unk. \\
11 & neg. \\
12 & neg. \\
13 & neg. \\
14 & FLT3/ITD, BAALC \\
15 & BAALC \\
16 & neg. \\
17 & BAALC \\
18 & unk. \\
19 & FLT3/ITD, BAALC \\
20 & neg. \\
21 & BAALC \\
22 & neg. \\
23 & NPM1, BAALC \\
24 & BAALC \\
25 & \\
\hline$-n$
\end{tabular}

neg.=negative; unk.=unknown;

al. [6] published in 2004. Cytogenetic samples were obtained at diagnosis and on the first day of documented morphologic CR following induction chemotherapy. Patients with abnormal cytogenetics at diagnosis, and normal cytogenetics at morphologic CR (NCR; $n=103$ ) were compared with those with abnormal cytogenetics both at diagnosis and at morphologic CR (ACR; $n=15$ ) for overall survival (OS), disease-free sur-

Table 4. Primary cytogenetic changes of 17 patients with hematologic but without cytogenetic complete remission

\begin{tabular}{|c|c|c|c|c|c|c|c|c|c|c|c|c|c|c|c|c|}
\hline Abn.|P.No. & 12 & 13 & 17 & 20 & 21 & 14 & 15 & 16 & 23 & 18 & 22 & 10 & 19 & 11 & 24 & 25 \\
\hline Complex karyotype & $\mathrm{X}$ & $\mathrm{X}$ & $\mathrm{X}$ & $\mathrm{X}$ & $\mathrm{X}$ & $\mathrm{X}$ & & & & & & & & $\mathrm{X}$ & & \\
\hline Abn. $5 q /-5$ & $\mathrm{X}$ & $\mathrm{X}$ & $\mathrm{X}$ & $\mathrm{X}$ & $\mathrm{X}$ & $\mathrm{X}$ & & & & & & & & & & \\
\hline Trisomy 8 & & & & & & & $\mathrm{X}$ & $\mathrm{X}$ & $\mathrm{X}$ & & & & & & & \\
\hline Abn. 3q & & & & & & & & & & $\mathrm{X}$ & $\mathrm{X}$ & & & & & \\
\hline Abn. 7q/-7 & & & & & & & & & & & & $\mathrm{X}$ & $\mathrm{X}$ & & & \\
\hline Abn. 12p & & & & & & & & & & & & & & $\mathrm{X}$ & & \\
\hline $\mathrm{t}(9 ; 11)(\mathrm{p} 22 ; \mathrm{p} 15)$ & & & & & & & & & & & & & & & $\mathrm{X}$ & \\
\hline Abn. $20 \mathrm{q}$ & & & & & & & & & & & & & & & & $\mathrm{X}$ \\
\hline
\end{tabular}

Abn.=abnormality; 


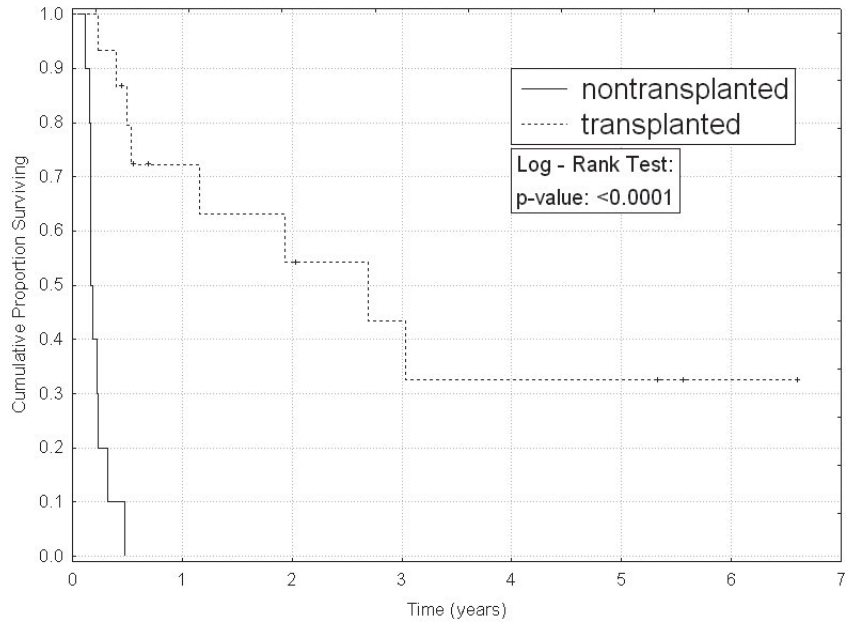

Figure 1. Comparison of progression free survival (Kaplan-Meier survival curves) between transplanted $(n=15)$ and nontransplanted $(n=10)$ patients from our cohort of 25 patients without $C R c$ after $7+3$ and $4+3$ regimens ( $\log$-Rank test, $\mathrm{P}<0.0001$ ), median progression free survival was 2.7 and 0.2 years respectively.

vival (DFS), and cumulative incidence of relapse (CIR). ACR patients had significantly shorter OS, DFS and higher CIR. The relative risk of relapse or death was 2.1 times higher for ACR patients than for NCR patients [6].

118 high-risk MDS or AML patients with an abnormal karyotype at diagnosis and a second cytogenetic analysis performed after induction chemotherapy were included in the retrospective study of German researchers in 2009 [7]. The authors confirmed that the persistence of minimal disease on a cytogenetic level in patients with de novo or secondary AML as well as high-risk MDS who achieved morphologic CR following conventional induction therapy was an independent prognostic parameter for the probability of shorter OS [7].

Data from 254 adult patients with AML (excluding acute promyelocytic leukaemia) who achieved CR after induction chemotherapy on various first-line protocols were examined by Chen et al. [8] in 2011. Persistent cytogenetically abnormal cells at CR predict a significantly shorter relapse-free survival and OS. SCT in CR1 may improve the clinical outcome of patients lacking cytogenetic remission after induction although this depends on patient selection [8].

Our study focused on AML patients with presumably very poor prognosis - patients, who did not achieve CRc after two chemotherapeutical attempts $(7+3$ and $4+3$ regimens). The frequency of patients with this condition can be estimated to be as high as $18 \%$ between consecutive AML patients. Some of these patients have normal karyotype and CRc cannot be evaluated. In our study, 25 AML patients without CRc, who had an abnormal karyotype at diagnosis, were analysed for clinical and laboratory parameters. Approximately a third of these patients did not achieve even morphologic CR.

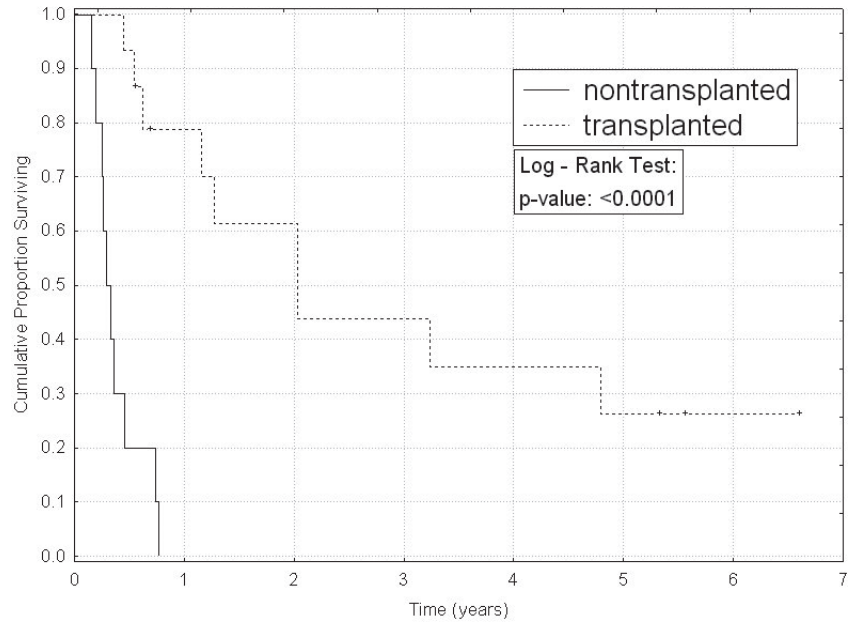

Figure 2. Comparison of overall survival (Kaplan-Meier survival curves) between transplanted $(n=15)$ and nontransplanted $(n=10)$ patients from our cohort of 25 patients without $C R c$ after $7+3$ and $4+3$ regimens (Log-Rank test, $\mathrm{P}<\mathbf{0 . 0 0 0 1}$ ), median overall survival was 2.0 and 0.3 years respectively.

Firstly, we compared two subgroups - with or without morphologic CR. Similar cytogenetic abnormalities were observed in both subgroups with myelodysplasia related changes being the most common. CK with deletion of $5 \mathrm{q}$, as suspected primary cytogenetic change, constituted approximately a third of all karyotypes in both subgroups. There were only two noncomplex karyotypes in the subgroup without morphologic CR. Interestingly, one of them had trisomy 8 as a sole abnormality. Molecular genetic analysis revealed NPM1 mutation and overexpression of BAALC in this patient. There were 5 patients with intermediate cytogenetics risk in the subgroup with morphologic CR. Three of them were positive for some of the negative prognostic markers tested in molecular genetic analyses. From cytogenetic point of view it is interesting that in $4 / 25$ patients subclones were diminished by the chemotherapy treatment, however cytogenetically less advanced clones proliferated.

Secondly, we made statistical analyses on other two subgroups - transplanted or nontransplanted patients. Allogeneic stem cell transplantation was found to be the only curative treatment for patients without CRc after $7+3$ and $4+3$ regimens. In our cohort, $40 \%$ of the patients, who underwent allo-SCT, are alive. Importantly, $67 \%$ of the patients, who died after allo-SCT, died of causes unrelated to progression of AML. Nonrelapse mortality is therefore one of the fields where survival of patients without CRc could be further improved. However, there is still a lack of knowledge and further studies are needed to explore this very important topic.

Supplementary information is available in the online version of the paper. 
Acknowledgements: The authors would like to thank Martina Hruba and Anna Rykovska for their technical support in the cytogenetic laboratory (Institute of Medical Genetics, Pilsen). We also thank all the clinical staff of the Department of Haematology and Oncology (University Hospital Pilsen) for their perfect patient care and cooperation. The work was supported in part by the project ED2.1.00/03.0076 from the European Regional Development Fund and from the Ministry of Health, Czech Republic - EU project CZ1.07./2.3.00/20.0040.

\section{References}

[1] SWERDLOW SH, CAPO E, HARRIS NL, JAFFE ES, PILERI SA, et al. WHO classification of tumours of haematopoietic and lymphoid tissues. Lyon: IARC, 2008.

[2] CHESON BD, BENNETT JM, KOPECKY KJ, BUCHNER T, WILLMAN CL, et al. Revised recommendations of the international working group for diagnosis, standardization of response criteria, treatment outcomes, and reporting standards for therapeutic trials in acute myeloid leukemia. J Clin Oncol 2003; 21: 4642-4649. http://dx.doi.org/10.1200/JCO.2003.04.036

[3] ISCN (2013): An International System for Human Cytogenetic Nomenclature, L.G.Shaffer, J.McGowan-Jordan, M.Schmid (eds); S. Karger, Basel 2013.

[4] GRIMWADE D, WALKER H, OLIVER F, WHEATLEY K, CLACK R, et al. What happens subsequently in AML when cytogenetic abnormalities persist at bone marrow harvest? Results of the 10th UK MRC AML Trial. Bone Marrow
Transplant 1997; 19: 1117-1123. http://dx.doi.org/10.1038/ sj.bmt. 1700804

[5] FUNG HC, STEIN A, SLOVAK ML, O'DONNELL MR, SNYDER DS, et al. A long-term follow-up report on allogeneic stem cell transplantation for patients with primary refractory acute myelogenous leukemia: impact of cytogenetic characteristics on transplantation outcome. Biol Blood Marrow Transplant 2003; 9: 766-771. http://dx.doi.org/10.1016/j. bbmt.2003.08.004

[6] MARCUCCI G, MROZEK K, RUPPERT AS, ARCHER KJ, PETTENATI MJ, et al. Abnormal cytogenetics at date of morphologic complete remission predicts short overall and disease-free survival, and higher relapse rate in adult acute myeloid leukemia: results from Cancer and Leukemia Group B Study 8461. J Clin Oncol 2004; 22: 2410-2418. http://dx.doi. org/10.1200/JCO.2004.03.023

[7] BALLEISEN S, KUENDGEN A, HILDEBRANDT B, HAAS R, GERMING U. Prognostic relevance of achieving cytogenetic remission in patients with acute myelogenous leukemia or high-risk myelodysplastic syndrome following induction chemotherapy. Leuk Res 2009; 33: 1189-1193. http://dx.doi. org/10.1016/j.leukres.2009.03.004

[8] CHEN Y, CORTES J, ESTROV Z, FADERL S, QIAO W, et al. Persistence of cytogenetic abnormalities at complete remission after induction in patients with acute myeloid leukemia: prognostic significance and the potential role of allogeneic stem-cell transplantation. J Clin Oncol 2011; 29: 2507-2513. http://dx.doi.org/10.1200/JCO.2010.34.2873 


\title{
Supplementary Information
}

\section{Allogeneic stem cell transplantation can improve outcome of AML patients without complete cytogenetic response after induction and consolidation treatment}

\author{
P. DVORAK ${ }^{1,2, *}$, D. LYSAK ${ }^{3}$, S. VOKURKA ${ }^{3}$, M. KARAS 3 , I. SUBRT ${ }^{1}$
}

${ }^{1}$ Institute of Medical Genetics, University Hospital Pilsen, Faculty of Medicine in Pilsen, Charles University in Prague, Pilsen, Czech Republic; ${ }^{2}$ Institute of Biology, Faculty of Medicine in Pilsen, Charles University in Prague, Pilsen, Czech Republic; ${ }^{3}$ Department of Haematology and Oncology, University Hospital Pilsen, Pilsen, Czech Republic

*Correspondence: Pavel.Dvorak@lfp.cuni.cz

\section{Supplementary Table}

Table S1. G-banding and FISH results of 9 patients without hematologic complete remission

\begin{tabular}{|c|c|c|}
\hline P. No. & At AML diagnosis & After $7+3$ and $4+3($ HiDAC $+\mathrm{Mx})$ \\
\hline \multirow[t]{2}{*}{1} & $\begin{array}{l}\text { 44,XX,del(4)(q2?7),-5,der(5)t(4;5)(?q27;q21),der(7)t(5;7)(q13;q22),?der(8), } \\
\operatorname{der}(9) \mathrm{t}(5 ; 9)(\mathrm{p} 13 ; \mathrm{q} 21), \operatorname{der}(12) \operatorname{del}(12)(\mathrm{p} 11) \operatorname{del}(12)(\mathrm{q} 21),-16[12] / \mathbf{4 6}, \mathbf{X X}[6]\end{array}$ & $\begin{array}{l}\text { 44,XX,del(4)(q2?7),-5,der(5)t(4;5)(?q27;q21),der(7)t(5;7)(q13;q22), } \\
\operatorname{der}(9) \mathrm{t}(5 ; 9)(\mathrm{p} 13 ; \mathrm{q} 21), \operatorname{der}(12) \operatorname{del}(12)(\mathrm{p} 11) \operatorname{del}(12)(\mathrm{q} 21),-16[8]\end{array}$ \\
\hline & $\begin{array}{l}\text { FISH: 85\% deletion EGR1(5q31),80\% deletion D7S486(7q31),75\% deletion } \\
\text { CBFB(16q22) }\end{array}$ & FISH: $\mathbf{9 0 \%}$ deletion EGR1, 90\% deletion D7S486 \\
\hline \multirow[t]{2}{*}{2} & $\begin{array}{l}\text { 68-71<3n>,XXY,+Y,del(5)(?q12q35),+del(5)(?q12q35),+6,del(7)(q22q36), der(7) } \\
\mathrm{t}(7 ; 17)(\mathrm{p} 14 ; ? \mathrm{p} 12) \times 2,+\operatorname{del}(7)(\mathrm{q} 22 \mathrm{q} 36),+8,-9,-10,-11,-13,+14,-16,-17,-18,+19,+20 \\
+\operatorname{der}(?) \mathrm{t}(17 ; ?)(? \mathrm{q} ; ?),+1-3 \operatorname{mar}[\mathrm{cp} 20]\end{array}$ & $\begin{array}{l}\text { 67-71<3n }>\text {,XXY,+Y,del(5)(?q12q35), }+\operatorname{del}(5)(? q 12 \mathrm{q} 35),+6, \operatorname{del}(7) \\
(\mathrm{q} 22 \mathrm{q} 36), \operatorname{der}(7) \mathrm{t}(7 ; 17)(\mathrm{p} 14 ; \text {; } 12) \times 2,+\operatorname{del}(7)(\mathrm{q} 22 \mathrm{q} 36),+8,-9,-10,-11,- \\
13,+14,-16,-17,-18,+19,+20,+\operatorname{der}(?) \mathrm{t}(17 ; ?)(? \mathrm{q} ; ?),+1-5 \operatorname{mar}[\mathrm{cp} 15]\end{array}$ \\
\hline & $\begin{array}{l}\text { FISH: } \mathbf{6 \%} \text { deletion EGR1(5q31),92\% deletion EGR1x2,10\% deletion } \\
\text { D7S486(7q31),87\% deletion D7S486x2,95\% tetrasomy } 8\end{array}$ & FISH: $\mathbf{9 0 \%}$ deletion EGR1x2,80\% trisomy 12 and disomy 13 \\
\hline 3 & $\begin{array}{l}\text { 45-46,X,der(X)t(X;?)(?),der(3)del(3)(?q)t(3;?6)(?q;?q24),der(6)t(3;6)(?q;q2?3),der(7) } \\
\operatorname{del}(7)(\mathrm{p} 12) \operatorname{del}(7)(\mathrm{q} 21),-14,-15,+\operatorname{der}(?) \mathrm{t}(\mathrm{X} ; ?)(?),+\operatorname{der}(?) \mathrm{t}(? ; 3)(?)[\mathrm{cp} 20]\end{array}$ & $\begin{array}{l}\text { Persistent massive infiltration by blasts of AML in bone marrow and } \\
\text { periferal blood by cytology, cytogenetic analysis not performed }\end{array}$ \\
\hline \multirow[t]{2}{*}{4} & $\begin{array}{l}\text { 45,XX,der }(1) \mathrm{t}(1 ; 6)(\mathrm{p} 33 ; ?), \operatorname{der}(6) \mathrm{t}(1 ; 6)(\mathrm{p} 33 ; \mathrm{q} 23) \mathrm{t}(6 ; 9)(\mathrm{p} 11 ; \mathrm{p} 1 ? 3),- \\
9[3] / \mathbf{4 6}, \mathbf{i d e m},+10[16]\end{array}$ & $\begin{array}{l}\text { 45,XX,der(1)t(1;6)(p33;?),der(6)t(1;6)(p33;q23)t(6;9)(p11;p1?3),- } \\
9[13] / \mathbf{4 6}, \mathbf{X X}[1]\end{array}$ \\
\hline & FISH: $\mathbf{9 0} \%$ deletion $9 \mathrm{q} 21, \mathbf{5 0} \%$ trisomy 10 & FISH: $\mathbf{8 0} \%$ deletion $9 \mathrm{q} 21,<\mathbf{1} \%$ trisomy 10 \\
\hline \multirow[t]{2}{*}{5} & $\begin{array}{l}\mathbf{4 6 , X X},+1, \operatorname{der}(5) \operatorname{del}(5)(\mathrm{q} 2 ? 2 \mathrm{q} 31) \operatorname{ins}(5)(\mathrm{q} 31 \mathrm{p} 15 \mathrm{p} 1 \text { ? } 1), \mathrm{i}(8)(\mathrm{q} 10),-17, \operatorname{der}(18) \\
\mathrm{t}(17 ; 18)(\mathrm{q} 11.1 ; \mathrm{p} 11.1)[4] / \mathbf{4 7}, \mathbf{s l},+\mathrm{i}(8)(\mathrm{q} 10)[10] / \mathbf{4 8}, \mathbf{s d 1 1},+\mathrm{i}(8)(\mathrm{q} 10)[3] / \mathbf{4 8}, \mathbf{s d l 1},+ \\
\operatorname{mar1}[1] / \mathbf{4 9}, \mathbf{s d l 1},+\operatorname{mar} 1,+\operatorname{mar} 2[1]\end{array}$ & $\begin{array}{l}\mathbf{4 6}, \mathbf{X X},+1, \operatorname{der}(5) \operatorname{del}(5)(\mathrm{q} 2 ? 2 \mathrm{q} 31) \operatorname{ins}(5)(\mathrm{q} 31 \mathrm{p} 15 \mathrm{p} 1 ? 1), \mathrm{i}(8) \\
(\mathrm{q} 10),-17, \operatorname{der}(18) \mathrm{t}(17 ; 18)(\mathrm{q} 11.1 ; \mathrm{p} 11.1)[2] / \mathbf{4 7}, \mathrm{sl},+\mathrm{i}(8)(\mathrm{q} 10) \\
{[9] / \mathbf{4 8}, \mathbf{s d l 1},+\mathrm{i}(8)(\mathrm{q} 10)[3]}\end{array}$ \\
\hline & $\begin{array}{l}\text { FISH: } \mathbf{9 9} \% \text { deletion EGR1(5q31),22\% trisomy ETO(8q22),52\% pentasomy } \\
\text { ETO,12\% septasomy ETO }\end{array}$ & $\begin{array}{l}\text { FISH: } \mathbf{9 0} \% \text { deletion EGR1,8\% trisomy ETO, } \mathbf{4 5 \%} \text { pentasomy } \\
\text { ETO,25\% septasomy ETO }\end{array}$ \\
\hline \multirow[t]{2}{*}{6} & $46, X Y, \operatorname{inv}(3)(q 21 q 26)[6] / 45$, idem, $-7[19]$ & $46, X Y, \operatorname{inv}(3)(q 21 q 26)[4] / 45$, idem,-7[13]/46,XY $[3]$ \\
\hline & FISH: $\mathbf{9 0 \%}$ traslocation EVI1 (3q26), 90\% monosomy 7 & FISH: $\mathbf{7 7 \%}$ traslocation EVI1, $\mathbf{8 4} \%$ monosomy 7 \\
\hline \multirow[t]{2}{*}{7} & $\begin{array}{l}\text { 46,XY,inv(3)(q21q26),t(4;12)(q2?5;p13), } \operatorname{der}(11) \operatorname{del}(11)(\mathrm{p} 11) \operatorname{del}(11)(\mathrm{q} 13) \\
\operatorname{der}(13) \mathrm{t}(11 ; 13)(\mathrm{p} 11 ; \mathrm{p} 11)[4] / 46, \mathbf{X Y}[1]\end{array}$ & $\begin{array}{l}\text { 46,XY,inv(3)(q21q26),t(4;12)(q2?5;p13), } \operatorname{der}(11) \operatorname{del}(11)(\mathrm{p} 11) \\
\operatorname{del}(11)(\mathrm{q} 13), \operatorname{der}(13) \mathrm{t}(11 ; 13)(\mathrm{p} 11 ; \mathrm{q} 11)[5] / \mathbf{4 6}, \mathrm{XY}[1]\end{array}$ \\
\hline & $\begin{array}{l}\text { FISH: } \mathbf{7 4 \%} \text { deletion MLL(11q23), 80\% deletion TEL(ETV6,12p13), } 70 \% \text { trans- } \\
\text { location EVI1(3q26) }\end{array}$ & FISH: 74\% deletion MLL(11q23) \\
\hline 8 & $47, \mathrm{XY},+8[3] / 46, \mathrm{XY}[16], \mathrm{FISH}: \mathbf{4 5} \%$ trisomy 8 & $47, \mathrm{XY},+8[1] / 46, \mathrm{XY}[14], \mathrm{FISH}: 3 \%$ trisomy 8 \\
\hline \multirow[t]{2}{*}{9} & $\begin{array}{l}\text { 46,XX,del(5)(q12q33)[2]/45,idem,der(7)(17?pter-17?p::7?p13-7?q11.2::17?q21- } \\
17 ? q 25:: 20 q 11.2-20 q \operatorname{qter}),-17, \operatorname{der}(20)(20 \text { pter-20q11.2::?17q-?17qter)[17] }\end{array}$ & G-banding unsuccessful \\
\hline & FISH: 85\% deletion EGR1 (5q31), 85\% deletion D7S486 (7q31) & FISH: $\mathbf{6 6 \%}$ deletion EGR1 \\
\hline
\end{tabular}




\begin{tabular}{|c|c|c|}
\hline P. No. & At AML diagnosis & After $7+3$ and $4+3($ HiDAC $+\mathrm{Mx})$ \\
\hline \multirow[t]{2}{*}{10} & 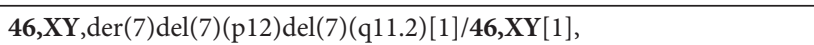 & G-banding unsuccessful \\
\hline & FISH: $\mathbf{7 5 \%}$ deletion D7S486(7q31), $\mathbf{1 4 \%}$ monosomy 7 & FISH: $\mathbf{9 \%}$ deletion D7S486, $\mathbf{4} \%$ monosomy 7 \\
\hline \multirow[t]{2}{*}{11} & $\begin{array}{l}\text { 46,XX,der(2)ins(2;16)(q31;q22q?)t(2;12)(q33;q21-23),del(7)(p11), } \\
\text { der(12)del(12)(p12)t(?2;12)(q33;q21-23),del(16)(q11)[3]/45,idem,-del(7) } \\
(\mathrm{p} 11)[11] / \mathbf{4 6}, \mathbf{X X}[1]\end{array}$ & $\begin{array}{l}\text { 46,XX,der(2)ins(2;16)(q31;q22q?)t(2;12)(q33;q21-23), del(7)(p11),der(12) } \\
\operatorname{del}(12)(12) \mathrm{t}(? 2 ; 12)(\mathrm{q} 33 ; \mathrm{q} 21-23), \operatorname{del}(16)(\mathrm{q} 11)[4] / \mathbf{4 6}, \mathbf{X X}[11],\end{array}$ \\
\hline & FISH: $\mathbf{9 3 \%}$ deletion TEL(ETV6), $\mathbf{8 0 \%}$ monosomy 7 & FISH: $\mathbf{2 0} \%$ deletion TEL(ETV6), $<\mathbf{1} \%$ monosomy 7 \\
\hline \multirow[t]{2}{*}{12} & $\begin{array}{l}\text { 42-45,XY, der(1)t(1;?)(p13;?),?i(1)(q10),-4,der(5)t(5;?)(?q14-21;?),del(7) } \\
(\mathrm{p} 11),-10, \operatorname{der}(11)(?),-12, \text { ?der(12)(?),der(15)t(15;?)(p11;?),-16,+der(18;21) } \\
(\mathrm{q} 10 ; \mathrm{q} 10),-19,+1-4 \operatorname{mar}[\mathrm{cp} 22]\end{array}$ & $\begin{array}{l}\mathbf{4 4 , X Y , d e l}(1)(\mathrm{p} 13),-4, \operatorname{der}(5) t(? 1 ; 5)(\mathrm{p} 13 ; \mathrm{q} 13), \operatorname{del}(7)(\mathrm{p} 10),-10,-11,-12,-15,- \\
16,-19,+5 \operatorname{mar}[1] / \mathbf{4 3}, \mathbf{i d e m},-18[1] / \mathbf{4 6}, \mathbf{X Y}[23]\end{array}$ \\
\hline & FISH: 78\% deletion EGR1(5q31), 82\% deletion TP53(17p13) & FISH: $\mathbf{1 2} \%$ deletion EGR1(5q31) \\
\hline \multirow[t]{2}{*}{13} & 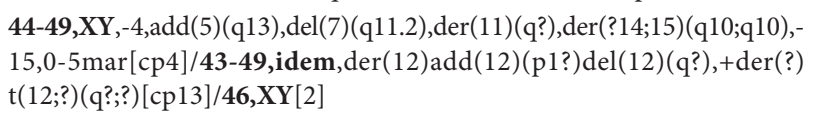 & $46, \mathrm{XY}[15]$ \\
\hline & $\begin{array}{l}\text { FISH: } \mathbf{9 1 \%} \text { deletion EGR1(5q31),92\% deletion 7q31(D7S486),96\% am- } \\
\text { plification MLL(11q23),70\% deletion TEL(ETV6, 12p13) }\end{array}$ & FISH: $\mathbf{8 \%}$ amplification MLL,7\% deletion TEL \\
\hline \multirow[t]{2}{*}{14} & $\begin{array}{l}\text { 46,XX,der(5)t }(5 ; 11)(\mathrm{q} 32-34 ; \mathrm{q} 14-22), \operatorname{del}(11)(\mathrm{q} 13), \operatorname{der}(12) \operatorname{ins}(12 ; 11) \\
(\mathrm{q} 24 ; \mathrm{q} 13 \mathrm{q} 14-22)[2] / 48, \mathrm{idem},+8,+13[13]\end{array}$ & $\begin{array}{l}\text { 48,XX,der(5)t(5;11)(q32-34;q14-22),+8, del(11)(q13),der(12)ins(12;11) } \\
(\mathrm{q} 24 ; \mathrm{q} 13 \mathrm{q} 14-22),+13[7] / \mathbf{4 6}, \mathbf{X X}[8]\end{array}$ \\
\hline & FISH: $\mathbf{5 7 \%}$ trisomy 8; deletion EGR1 (5q31) and MLL negative & FISH: $\mathbf{8 0} \%$ trisomy 8 \\
\hline \multirow[t]{2}{*}{15} & $47, \mathrm{XY},+8[8] / 48, \mathrm{XY},+8,+21[12]$ & $47, \mathbf{X Y},+8[9] / 48, \mathbf{X Y},+8,+21[6]$ \\
\hline & $\begin{array}{l}\text { FISH: } \mathbf{5 0} \% \text { trisomy ETO(8q22)+trisomy AML1(21q22), } \mathbf{4 0} \% \text { trisomy } \\
\text { ETO(8q22) }\end{array}$ & $\begin{array}{l}\text { FISH: } \mathbf{5 0} \% \text { trisomy ETO(8q22)+trisomy AML1(21q22), } \mathbf{4 0} \% \text { trisomy } \\
\text { ETO(8q22) }\end{array}$ \\
\hline 16 & $\mathbf{4 7 , X X},+8[13] / \mathbf{4 6}, \mathrm{XX}[3]$, FISH: $\mathbf{5 6} \%$ trisomy 8 & $46, \mathrm{XX}[15]$, FISH: $10 \%$ trisomy 8 \\
\hline \multirow[t]{2}{*}{17} & $\begin{array}{l}\text { 47,X,der(Y)t(Y;13)(p11.3;q22),-3,der(5)ins(5;3)(p1?4;?)del(5)(q12), } \\
+\operatorname{der}(5) \operatorname{ins}(5 ; 3)(\mathrm{p} 1 ? 4 ; ?) \operatorname{del}(5)(\mathrm{q} 12),+8, \operatorname{del}(13)(\mathrm{q} 13), \operatorname{del}(20)(\mathrm{q} 11.1) \\
{[19] / \mathbf{4 6}, \mathbf{X Y}[1]}\end{array}$ & $\begin{array}{l}\mathbf{4 6 , X Y}, \operatorname{der}(3) \mathrm{t}(3 ; ? 5)(\mathrm{p} 21 ; \mathrm{p} 1 ? 4),-5,+8[2] / \mathbf{4 8}, \mathbf{X Y},-3, \operatorname{der}(5) \operatorname{ins}(5 ; 3)(\mathrm{p} 1 ? 4 ; ?) \\
\operatorname{del}(5)(\mathrm{q} 12),+\operatorname{der}(5) \operatorname{ins}(5 ; 3)(\mathrm{p} 1 ? 4 ; ?) \operatorname{del}(5)(\mathrm{q} 12),+8,+? \operatorname{del}(20)(\mathrm{q} 11.1) \\
{[5] / \mathbf{4 6}, \mathbf{X Y}[11]}\end{array}$ \\
\hline & $\begin{array}{l}\text { FISH: } \mathbf{8 6} \% \text { deletion EGR1(5q31), } \mathbf{8 7} \% \text { trisomy } 8, \mathbf{8 8} \% \text { deletion } \\
\text { D20S108(20q12) }\end{array}$ & FISH: $\mathbf{6 3} \%$ deletion EGR1(5q31), $\mathbf{5 4 \%}$ trisomy 8 \\
\hline 18 & 46,XX,t(2;3)(p13;q26)[15], FISH: 95\% translocation EVI1 & 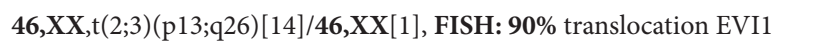 \\
\hline \multirow[t]{2}{*}{19} & $46, \mathbf{X X}, \operatorname{del}(7)(\mathrm{q} 22 \mathrm{q} 36)[4] / 46, \mathrm{XX}[16]$ & $46, \mathrm{XX}[20]$ \\
\hline & FISH: $\mathbf{3 1 \%}$ deletion D7S486 (7q31), 18\% deletion 9q21 & FISH: $2 \%$ deletion D7S486 \\
\hline \multirow[t]{2}{*}{20} & $\begin{array}{l}\text { 49-61,XY, }+\mathrm{X},+1,+1,+3,+4,+5, \operatorname{del}(5)(? \mathrm{q} 15 \mathrm{q} 33),+6,+7,+7, \operatorname{del}(7) \\
(? \mathrm{q} 22 \mathrm{q} 36),+8,+9,+11, \operatorname{der}(11) \operatorname{del}(11)(\mathrm{p} 11.2) \operatorname{del}(11)(\mathrm{q} 12), \operatorname{der}(11) \mathrm{t}(11 ; ?) \\
(\mathrm{q} 21 ; ?),+12, \operatorname{del}(13)(? \mathrm{q} 12 \mathrm{q} 14),+\operatorname{del}(13)(? \mathrm{q} 12 \mathrm{q} 14), \operatorname{der}(13) \mathrm{t}(13 ; ?)(? ; ?),+15,+ \\
17,+18,+19,+20,+\operatorname{der}(?) \mathrm{t}(11 ; ?)(\mathrm{q} 21 ; ?),+\operatorname{der}(?) \mathrm{t}(13 ; ?)(? ; ?),+1-2 \operatorname{mar}[\mathrm{cp} 20]\end{array}$ & 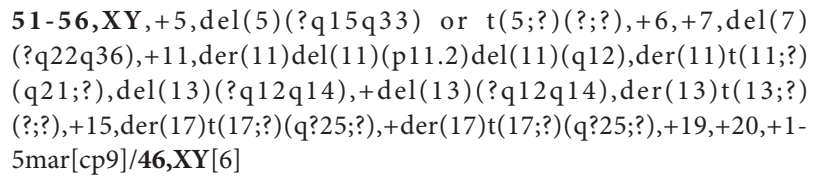 \\
\hline & $\begin{array}{l}\text { FISH: } \mathbf{8 0} \% \text { deletion EGR1(5q31), 79\% deletion D7S486(7q31), } \mathbf{6 2} \% \\
\text { trisomy } 17\end{array}$ & FISH: $\mathbf{1 8} \%$ deletion EGR1(5q31), 20\% trisomy 17 \\
\hline \multirow[t]{2}{*}{21} & $\begin{array}{l}\text { 41,XX,del(5)(q14-21q32-34), der(11)t(11;12)(p15;q13),-12,der(13;22) } \\
(\mathrm{q} 10 ; \mathrm{q} 10), \operatorname{der}(14 ; 15)(\mathrm{q} 10 ; \mathrm{q} 10),-17, \operatorname{der}(? 21)(21 \mathrm{qter} \rightarrow 21 \mathrm{q} 21:: 22 \mathrm{q} 11.2 \rightarrow 22 \\
\mathrm{q} 12:: 21 \mathrm{p} 11.2 \rightarrow 21 \mathrm{q} 21:: 21 \mathrm{q} 11.2 \rightarrow 21 \mathrm{q} t e r),-22[11] / \mathbf{4 6}, \mathbf{X X}[9]\end{array}$ & $\mathbf{4 6}, \mathbf{X X}, \operatorname{del}(5)(\mathrm{q} 14-21 \mathrm{q} 32-34)[2] / \mathbf{4 6}, \mathbf{X X}[13]$ \\
\hline & FISH: 56\% deletion EGR1(5q31), $\mathbf{6 1 \%}$ monosomy 17 & FISH: 6\% deletion EGR1; monosomy 17 negative \\
\hline 22 & 45,XX,t(3;3)(q21;q26),-7[14]/46,XX[1], FISH: $91 \%$ monosomy 7 & $\mathbf{4 5 , X X , t ( 3 ; 3 ) ( q 2 1 ; q 2 6 ) , - 7 [ 1 ] / 4 6 , X X [ 9 ] , ~ F I S H : ~} \mathbf{1 , 5} \%$ monosomy 7 \\
\hline 23 & $\mathbf{4 7 , X X},+8[9] / \mathbf{4 6 , X X}[8]$, FISH: $\mathbf{7 3} \%$ trisomy 8 & $\mathbf{4 6 , X X}$ [15], FISH: $\mathbf{1 , 5} \%$ trisomy 8 \\
\hline 24 & $46, \mathrm{XX}, \mathrm{t}(9 ; 11)(\mathrm{p} 22 ; \mathrm{p} 15)[20]$ & $\mathbf{4 6}, \mathbf{X X}, \mathrm{t}(9 ; 11)(\mathrm{p} 22 ; \mathrm{p} 15)[1] / 46, \mathbf{X X}[19]$ \\
\hline 25 & 46,XY,del(20)(q11.2)[20], FISH: 97\% deletion D20S108(20q12) & 46,XY,del(20)(q11.2)[11]/46,XY[3], FISH: 80\% deletion D20S108 \\
\hline
\end{tabular}

